\title{
Kualitas Muffin Dengan Kombinasi Tepung Pisang Kepok Putih (Musa paradisiaca forma typica) Dan Tepung Labu Kuning (Cucurbita moschata)
}

\section{The Quality Of Muffin With A Combination Of White Kepok Banana (Musa paradisiaca forma typica) And Butternut Pumpkin (Cucurbita moschata)}

\author{
Cindy Yong Kurnia Putri ${ }^{1}$, Fransiskus Sinung Pranata ${ }^{1 *}$, Yuliana Reni Swasti ${ }^{1}$

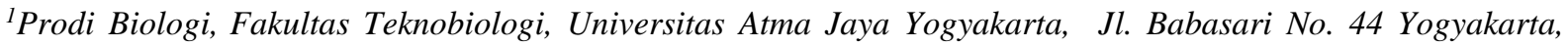 \\ Indonesia \\ Email:sinung.pranata@uajy.ac.id_ *Penulis Korespondensi
}

\begin{abstract}
Muffins are quick bread that does not require time for cooking, development and resting. A distinctive feature of muffins is the surface of the bread in the form of crust, symmetrical and golden brown. The use of white Kepok banana flour and pumpkin flour in the muffin making process is useful for increasing the fiber and beta-carotene content. This study was aimed to determine the quality of muffin products made from white Kepok banana flour and pumpkin flour based on chemical, physical, microbiological and organoleptic parameters. This study is also useful in order to find out the concentration of the best white Kepok banana flour and pumpkin flour combination in making muffins. This study uses a completely randomized design with a combination of white Kepok banana flour and pumpkin flour of 100: $0: 0$ as a control, 80: 15: 5, 80:10:10 and 80: 5: 15. The results obtained from muffin products have a moisture content of 17,80-21,33 \%, 0,43-0,99 \% ash content, 8,06-11,14 \% protein content, 20,19-23,27 \% fat content, carbohydrate levels of 46,63-49,73 \%, crude fiber content of 3,28-6,60 \%, soluble fiber content of $1,40-4,37 \%$, dietary fiber content of 4,68-10,98 \%, beta-carotene levels 470,56-3724,13 $\mu \mathrm{g} / 100 \mathrm{~g}$ and microbiological tests consisting of total plate and yeast molds that have met SNI standards for sweet bread (SNI-3840-1995). Muffins with a combination of white Kepok banana flour and pumpkin flour which have the best quality are 80: 15: 5 observed from physical, chemical, microbiological and organoleptic parameters.
\end{abstract}

Keywords: Muffins, Kepok White Banana Flour, Butternut Pumpkin

\begin{abstract}
Abstrak
Muffin merupakan quick bread yang tidak memerlukan waktu pengulenan, pengembangan dan pengistirahatan. Ciri khas muffin adalah permukaan roti berupa crust merekah secara simetris dan berwarna cokelat keemasan. Penggunaan tepung pisang kepok putih dan tepung labu kuning pada proses pembuatan muffin berguna untuk meningkatkan kandungan serat dan betakaroten. Tujuan dari penelitian ini adalah mengetahui kualitas produk muffin berbahan baku tepung pisang kepok putih dan tepung labu kuning dari parameter kimia, fisik, mikrobiologi dan organoleptik. Penelitian ini juga berguna agar dapat mengetahui konsentrasi dari kombinasi yang terbaik pada tepung pisang kepok putih dan tepung labu kuning dalam pembuatan muffin. Penelitian ini menggunakan Rancangan Acak Lengkap dengan kombinasi tepung pisang kepok putih dan tepung labu kuning sebesar 100:0:0 sebagai kontrol, 80:15:5, 80:10:10 dan 80:5:15. Hasil penelitian yang diperoleh dari produk muffin memiliki kadar air sebesar 17,80-21,33 \%, kadar abu 0,430,99 \%, kadar protein 8,06-11,14 \%, kadar lemak 20,19-23,27 \%, kadar karbohidrat 46,6349,73 \%, kadar serat kasar 3,28-6,60 \%, kadar serat larut 1,40-4,37 \%, kadar serat pangan 4,68-10,98 \%, kadar betakaroten 470,56-3724,13 $\mu \mathrm{g} / 100 \mathrm{~g}$ serta uji mikrobiologi yang terdiri dari angka lempeng total dan kapang khamir yang telah memenuhi standar SNI roti manis (SNI-3840-1995). Muffin dengan kombinasi tepung pisang kepok putih dan tepung labu kuning yang memiliki kualitas terbaik adalah 80:15:5 dilihat dari parameter fisik, kimia, mikrobiologi dan organoleptik.
\end{abstract}

Kata Kunci : Muffin, Tepung Pisang Kepok Putih, Tepung Labu Kuning 


\section{Pendahuluan}

Seiring perkembangan waktu, ketersediaan bahan pangan di Indonesia semakin banyak, sehingga dapat memicu potensi keanekaragaman pangan yang dapat divariasi dalam bentuk substitusi dan kombinasi dalam industri bakery. Penggunaan tepung lokal menjadi jalan alternatif bagi industri bakery karena tingginya potensi bahan baku pangan lokal sebagai pengganti tepung gandum, sehingga dapat dikaji penggunaannya sebagai diversifikasi bahan pangan dan untuk meningkatkan keinginan produsen bakery dalam berinovasi dan memanfaatkan tepung lokal atau non terigu (Hardiman, 2011).

Bahan pangan lokal yang dapat digunakan dan dimanfaatkan sebagai bahan baku tepung lokal atau non terigu sebagai sumber diversifikasi diantaranya adalah buah pisang kepok putih dan labu kuning. Pisang kepok putih merupakan pisang terbaik yang sebagai bahan tepung karena menghasilkan warna tepung paling putih dan memiliki kandungan pati serta karbohidrat yang tinggi dibandingkan dengan pisang lain (Ambarita dkk., 2015). Sementara labu kuning mengandung betakaroten, serat, karbohidrat, protein serta beberapa macam mineral seperti zat besi, fosfor, dan kalsium (Cahyaningtyas dkk., 2014).

Muffin adalah salah satu produk pengembangan roti yang memiliki ciri-ciri berupa crust pada permukaannya secara simetris dan tidak memerlukan volume pengembangan yang tinggi (Purnomo dkk., 2012). Cara untuk meminimalkan penggunaan tepung gandum dalam pembuatan muffin yaitu mengganti tepung gandum dengan bahan pangan lokal yang tinggi akan karbohidrat seperti penggunaan kombinasi tepung pisang kepok putih dan tepung labu kuning (Lionora dkk., 2013). Muffin dengan kombinasi tepung gandum, tepung pisang kepok putih dan tepung labu kuning diharapkan dapat menghasilkan karakteristik muffin dengan kualitas yang baik dan meningkatkan nilai gizi pada muffin.

\section{Metode Penelitian}

\section{Alat}

Alat yang digunakan dalam penelitian ini adalah loyang, baskom, pisau, mixer miyako, panci, oven Ecocell, kantong plastik, gloves, masker, texture analyzer, komputer, probe, inkubator Memert, Laminar Air Flow (LAF) ESCO AVC-3A1, autoklaf Hirayama Hiclave dengan seri HVE 50, neraca analitik Ohaus, moisture balancePhoenix Instrument, rak tabung reaksi, batu didih, statif, pipet tetes, mortar, cawanporselin, lampu bunsen, timbangan analitik, mikropipet, mikropipet tip, kertas saring, corong, trigalski, buret, tabung reaksi, gelas beker, kertas label, labu destilasi, soxhlet Isopad, erlenmeyer, cawan petri, lemari asam Biobase, desikator, microwave Electrolux, tanur Thermolyne, statif, moisture balance, alumunium foil, peeler, plastic wrap, penjepit, vortex Bastead Thermolyne, sendok, cup muffin, ayakan 80 mesh, ayakan 60 mesh, blender, kompor gas Rinnai, oven, toples, labu Kjedahl, gelas pengaduk, kertas payung, karet gelang, kapas, cawan alumunium, eksikator, colony counter, chromamometer Konica Minolta CR-10, spektrofotometer Shimadzu UV-1800, diagram kromatisasi CIE, tisu, gelas ukur, pipet ukur dan propipet.

\section{Bahan}

Bahan yang diperlukan dalam penelitian adalah gula halus Barokah, pisang kepok putih, tepung labu kuning, susu Dancow, telur, baking powder Koepoe-koepoe, tepung gandum Segitiga Biru dan butter Wijsman. Bahan yang digunakan dalam analisis fisik, kimia dan mikrobiologi adalah N-Heksane, $\mathrm{H}_{2} \mathrm{SO}_{4}$ pekat, katalis $\mathrm{N}, \mathrm{NaOH} 40 \%$, MrBCG, $\mathrm{HCl} 0,02 \mathrm{~N}$, alkohol $70 \%, \mathrm{H}_{2} \mathrm{SO}_{4} 1,25 \%$, $\mathrm{NaOH} 3,25 \%$, etanol $96 \%$, celite, aseton, petroleum eter (PE), bubuk $\beta$-karoten, $\mathrm{Na}_{2} \mathrm{SO}_{4}$ anhidrat, aquades, Potato Dextrose Agar dan Plate Count Agar.

\section{Metode}

Penelitian ini menggunakan Rancangan Acak Lengkap (RAL) dengan $3 x$ pengulangan dalam 4 variasi substitusi tepung pisang kepok putih dan tepung labu kuning (100:0:0), (80:15:5), (80:10:10) dan (80:5:15). Tahapan penelitian meliputi pembuatan tepung pisang kepok putih, uji pendahuluan tepung labu kuning, pembuatan muffin, uji kimia (kadar air, kadar abu, kadar lemak, kadar protein, kadar karbohidrat, kadar serat kasar, kadar serat larut, kadar serat pangan dan kadar betakaroten), uji sifat fisik (uji warna dan tekstur), uji mikrobiologi (uji Angka Lempeng Total dan Kapang Khamir), uji organoleptik dan analisis data menggunakan ANAVA dan 
dilanjutkan oleh Duncan Multiple Range Test (DMRT) untuk mengetahui letak beda nyata antarperlakuan dengan tingkat kepercayaan 95 $\%$.

\section{Hasil dan Pembahasan}

\section{Analisis Proksimat Tepung Pisang Kepok Putih}

Berdasarkan penelitian yang telah dilakukan, diperoleh hasil proksimat pisang kepok putih yang dapat dilihat pada Tabel 1 .

Tabel 1. Hasil Analisis Komposisi Kimia Tepung Pisang Kepok Putih

\begin{tabular}{ccc}
\hline \hline Komposisi & Hasil Analisis (\%) & Ferdiana (2016) (\%) \\
\hline \hline Air & 6,78 & 6,80 \\
Labu & 2,95 & 3,33 \\
Lemak & 3,41 & 3,43 \\
Protein & 1,54 & 10,60 \\
Karbohidrat & 84,83 & 75,84 \\
Serat Kasar & 4,09 & 2,28 \\
Serat Larut & 3,68 & - \\
Serat Total & 7,77 & - \\
\hline \hline
\end{tabular}

Kadar air yang diperoleh pada tepung pisang kepok putih sebesar $6,78 \%$. Jumlah kadar air pada tepung pisang kepok putih dapat memengaruhi umur simpan pada produk makanan yang dihasilkan khususnya pada muffin. Air adalah komponen yang sangat penting di dalam bahan makanan karena dapat memengaruhi tekstur, penampakan dan cita rasa pada produk pangan sehingga kadar air dapat menentukan kesegaran dan daya tahan pada bahan tersebut (Winarno, 2004).

Kadar abu merupakan kandungan residu bahan anorganik yang tersisa setelah bahan dibakar hingga bebas karbon untuk mengetahui kandungan mineral pada produk pangan (Papunas dkk., 2013). Kadar abu pada tepung pisang kepok putih yakni sebesar 2,95\%. Pisang kepok putih memiliki kandungan mineral yang tinggi seperti fosfor sebesar 42 $\mathrm{mg}$ dan besi sebesar 1,2 mg dalam setiap $100 \mathrm{~g}$ sehingga dapat menghasilkan kadar abu yang tinggi (Departemen Kesehatan RI, 1990).

Kadar protein yang diperoleh sebesar $3,41 \%$. Hasil ini sesuai dengan penelitian menurut Antartika dkk. (2004) bahwa kadar protein didalam tepung pisang sebesar 3,36$4,92 \%$. Kandungan protein pada tepung pisang kepok putih dapat disebabkan karena sifat kelarutan protein pada berbagai pelarut yaitu albumin yang larut di dalam air, polmin yang dapat larut dalam etanol, glutelin dapat larut pada $\mathrm{NaOH}$, globulin larut di dalam garam serta skleroprotein pada varietas pisang yang mengakibatkan perbedaan kadar protein pada tepung pisang tersebut (Kadir, 2005).

Kadar lemak tepung pisang kepok putih yang dihasilkan sebesar 1,54\%. Kadar lemak pada tepung pisang dapat mempengaruhi sifat reologis tepung terutama produk akhir. Kandungan lemak berada pada ikatan amilosalipid kompleks di dalam granula pati tepung dan bersifat tidak larut dalam air namun terpisah pada temperatur tinggi sebesar $80{ }^{\circ} \mathrm{C}$ (Kusnandar, 2010). Apabila kandungan amilosa-lipid tinggi maka mudah mengalami ketengikan. Tepung pisang yang diinginkan sebagai bahan baku industri adalah tepung pisang berkadar lemak rendah (Kadir, 2005).

Kadar karbohidrat yang diperoleh sebesar $84,83 \%$. Hasil penelitian ini lebih tinggi dibandingkan dengan hasil penelitian menurut Ferdiana (2016) sebesar 75,84\% dan menurut Murtiningsih dan Muhajir (1990) sebesar 76,47 \%. Penentuan kandungan karbohidrat dengan metode Carbohydrate by Difference dengan mengurangi $100 \%$ dari jumlah kadar air, kadar abu, kadar lemak serta kadar protein sehingga kadar karbohidrat yang dihasilkan lebih tinggi (Kusnandar, 2010).

Kadar serat kasar yang diperoleh sebesar $4,09 \%$ sedangkan kadar serat menurut Ferdiana (2016) sebesar 2,28\%. Perbedaan kadar serat kasar disebabkan karena dinding sel dari bahan telah terurai selama proses pengolahan dan pengeringan (Suladra, 2017). Kadar serat larut tepung pisang kepok putih 
sebesar 3,68 \%. Inulin adalah prebiotik bersifat serat larut dalam air yang tidak dapat dicerna oleh enzim pencernaan berupa $\alpha$-amilase. Inulin berguna dalam pertumbuhan bakteri asam laktat yang bersifat protektif terhadap probiotik sehingga dapat meningkatkan aktivitas serta ketahanan hidup probiotik selama masa penyimpanan (Pratiwi dan Rustanti, 2015).

\section{Analisis Proksimat Tepung Labu Kuning}

Hasil analisis proksimat tepung labu kuning dapat dilihat pada Tabel 2.

Tabel 2. Hasil Analisis Komposisi Kimia Tepung Labu Kuning

\begin{tabular}{ccccc}
\hline \hline Komposisi & Hasil Analisis $(\boldsymbol{\%})$ & $\begin{array}{c}\text { Nugroho (2015) } \\
(\boldsymbol{\%})\end{array}$ & $\begin{array}{c}\text { Sunjoto (2017) } \\
(\boldsymbol{\%})\end{array}$ & $\begin{array}{c}\text { Trisnawati } \\
(\mathbf{2 0 1 4}) \mathbf{( \% )}\end{array}$ \\
\hline \hline Air & 3,29 & 12,4 & 3,37 & 6,37 \\
Labu & 6,23 & 7,74 & 7,73 & 5,39 \\
Lemak & 2,17 & 4,83 & 4,49 & 1,16 \\
Protein & 7,82 & 3,42 & 8,16 & 5,06 \\
Karbohidrat & 80,49 & 71,61 & 76,25 & 82,02 \\
Serat Kasar & 6,55 & 4,28 & 6,53 & 9,51 \\
Serat Larut & 5,28 & 5,12 & - & 5,30 \\
Serat Pangan & 11,83 & - & - & 14,81 \\
Betakaroten & $25,835,73 \mu \mathrm{g} / 100 \mathrm{~g}$ & $46,602,85 \mu \mathrm{g} / 100 \mathrm{~g}$ & $23,675,94 \mu \mathrm{g} / 100 \mathrm{~g}$ & $21,472 \mu \mathrm{g} / 100 \mathrm{~g}$ \\
\hline \hline
\end{tabular}

Kadar air pada tepung labu kuning sebesar 3,29\%. Perbedaan dalam ketebalan dalam mengiris, suhu dan waktu dalam pengeringan dapat memengaruhi kadar air suatu tepung yang dihasilkan (Pratama, 2011). Semakin tinggi suhu pengeringan serta semakin lama waktu pengeringan maka semakin banyak pula jumlah air yang dapat diuapkan. Semakin tebal bahan yang dikeringkan maka penguapan air yang terjadi semakin lambat maka diperlukan waktu yang semakin lama (Hutabarat, 2012).

Kadar abu pada tepung labu kuning diperoleh hasil sebesar 6,23\%. Kandungan labu kuning berupa kalsium sebesar $45 \mathrm{mg}$ / $100 \mathrm{~g}$, fosfor sebesar $64 \mathrm{mg} / 100 \mathrm{~g}$ dan zat besi sebesar $1,4 \mathrm{mg} / 100 \mathrm{~g}$ yang dapat mendominasi kandungan mineral dan mempengaruhi kadar abu pada tepung labu kuning yang dihasilkan (Iqfar, 2012).Hasil analisis kadar protein pada tepung labu kuning sebesar 7,82\%. Proses pengolahan tepung labu kuning dilakukan dengan pemanasan pada suhu $65{ }^{\circ} \mathrm{C}$. Proses pemanasan pada suhu 55$75{ }^{\circ} \mathrm{C}$ dapat mengakibatkan denaturasi protein dengan perubahan struktur tersier protein namun tidak menyebabkan perubahan susunan asam aminonya (Kusnandar, 2010).

Kadar lemak yang diperoleh sebesar $3,17 \%$. Proses pemanasan pada suhu diatas 60 ${ }^{\circ} \mathrm{C}$ mengakibatkan lemak terhidrolisis membentuk asam lemak bebas dan gliserol sehingga ikatan pada gliserin dapat pecah sehingga menyebabkan lepasnya dua molekul air dan membentuk senyawa akrolein yang bersifat volatil (Kusnandar, 2010). Kadar karbohidrat pada tepung labu kuning sebesar $80,49 \%$. Perhitungan kadar karbohidrat metode Carbohydrate by Difference dengan cara mengurangi $100 \%$ dari penjumlahan kadar air, kadar abu, kadar protein serta kadar lemak sehingga kadar karbohidrat yang diperoleh lebih tinggi (Kusnandar, 2010).

Kadar serat kasar pada tepung labu kuning sebesar 6,55 \%. Labu kuning mengandung IDF (Insoluble Dietary Fiber) terdiri dari lignin $(4,3 \mathrm{~g} / 100 \mathrm{~g})$, selulosa $(40,4 \mathrm{~g} / 100 \mathrm{~g})$ dan hemiselulosa $(4,3 \mathrm{~g} / 100 \mathrm{~g})$ (See dkk., 2007). Proses pengolahan bahan pangan dapat mempengaruhi total kadar serat produk. Proses pengolahan terdiri dari penghancuran (grinding), pengeringan, pemanasan dapat mengubah komponen serat (Dhingra dkk., 2012).

Kadar serat larut tepung labu kuning sebesar 5,28 \%. Labu kuning mengandung pektin sebagai serat larut sebesar 1,26\% (Ramachandran dkk., 2017). Sifat pektin ini mampu menahan air serta membentuk gel serta tergolong dalam jenis serat yang dapat membentuk gel pada saat melewati usus halus serta mampu difermentasi oleh mikroflora usus besar (Fairudz dan Nisa, 2015). 
Kadar betakaroten pada tepung labu kuning sebesar 25.835,73 $\mu \mathrm{g} / 100 \mathrm{~g}$. Perlakuan panas dan pemasakan pada buah labu kuning mengakibatkan penurunan sebagian besar nutrisi namun dapat mengalami peningkatan karotenoid. Betakaroten dapat bekerja dengan stabil apabila berada pada suhu $60-70{ }^{\circ} \mathrm{C}$ selama proses pemanasan serta perubahan warna (decoloration) yang terjadi pada betakaroten secara enzimatik dari kuning cerah hingga kuning menuju kecoklatan pada suhu pemanasan $35^{\circ} \mathrm{C}$ (Marty dan Berset, 1990).

\section{Kadar Air}

Hasil analisis kadar air muffin kombinasi tepung pisang kapok putih dan tepung labu kuning menunjukkan bahwa kadar air muffin berkisar antara 17-21\%. Hasil kadar air muffin bervariasi, namun masih sesuai dengan SNI roti manis (1995) maksimal $40 \%$. Hasil analisis memiliki hasil yang berbeda nyata dengan tingkat kepercayaan $95 \%$.

\section{Analisis Kimia Muffin}

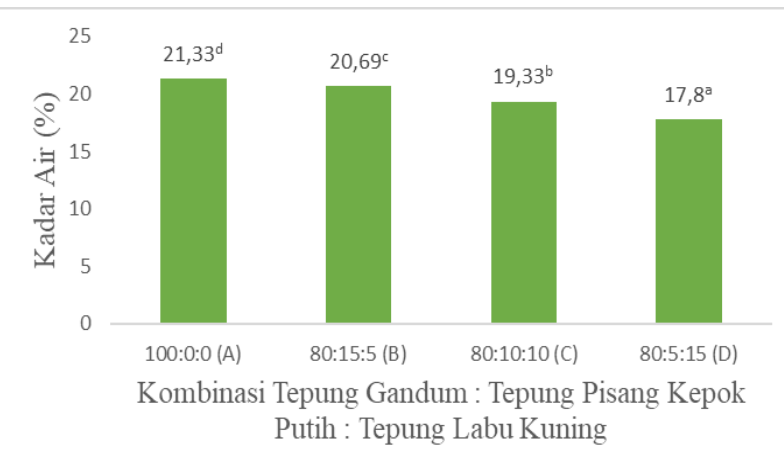

Gambar 1. Kadar Air Muffin dengan Kombinasi Tepung Pisang Kepok Putih dan Tepung Labu Kuning

Muffin kombinasi tepung pisang kapok putih dan tepung labu kuning dapat menghasilkan hasil beda nyata dengan muffin kontrol.

Penurunan kadar air disebabkan karena pada tepung labu kuning memiliki kandungan amilosa sebesar 19,07\% (Yin dan Wang, 2016), sedangkan pada pisang kapok putih sebesar 13,56\% (Nurhayati, 2014) sehingga semakin banyak tepung labu kuning maka kadar air akan mengalami penurunan. Kandungan amilosa yang makin meningkatakan menurunkan kadar air karena memiliki kemampuan membentuk gel dan lapisan film semakin tinggi (Kusnandar, 2010).

Struktur amilosa yang linier dan mengandung gugus hidroksil sehingga lebih mudah berikatan dengan ikatan hidrogen dibandingkan amilopektin.
Kandungan amilosa semakin meningkat dapat menurunkan kadar air sedangkan semakin tinggi amilopektin maka membentuk ikatan hidrogen yang relatif lemah. Amilosa dapat terlepas pada saat pemanasan diakibatkan amilosa terletak bebas di dalam granula pati (Kusnandar, 2010).

\section{Kadar Abu}

Hasil analisis kadar abu muffin kombinasi tepung pisang kapok putih dan tepung labu kuning menunjukkan bahwa kadar abu muffin berkisar antara 0,43-0,99 \%. Hasil kadar abu muffin telah sesuai dengan standar SNI roti manis (1995) maksimal $1 \%$. Hasil analisis memiliki hasil yang berbeda nyata antara perlakuan kontrol dengan perlakuan kombinasi. 


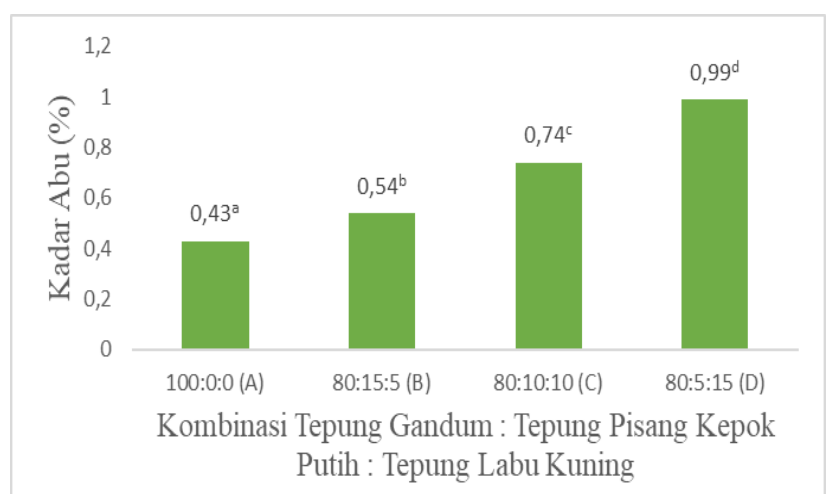

Gambar 2. Kadar Abu Muffin dengan Kombinasi Tepung Pisang Kepok Putih dan Tepung Labu Kuning

Kenaikan kadar abu disebabkan karena kandungan mineral yang terkandung pada tepung labu kuning memiliki kadar mineral sebesar 6,23\%, sedangkan tepung pisang kapok putih sebesar $2,95 \%$, sehingga semakin banyak penambahan tepung labu kuning maka kadar abu akan mengalami kenaikan. Penggunaan tepung pisang kepok putih dan tepung labu kuning dapat meningkatkan kadar abu karena pisang kepok putih mengandung fosfor $(42 \mathrm{mg} / 100 \mathrm{~g})$, potassium $(400 \mathrm{mg} / 100 \mathrm{~g}$ ) dan besi (1,2 mg/100g) (Iqfar, 2012).

\section{Kadar Lemak}

Hasil analisis kadar lemak muffin dengan kombinasi tepung pisang kapok putih dan tepung labu kuning berkisar antara 20,19-23,27\%. Hasil analisis memiliki hasil yang berbeda nyata antara perlakuan kontrol dengan perlakuan kombinasi. Kadar lemak yang diperoleh tidak memenuhi standar SNI roti manis (1995) maksimal 3\% karena terdapat perbedaan jumlah komposisi butter yang digunakan pada pembuatan roti manis dengan pembuatan muffin.

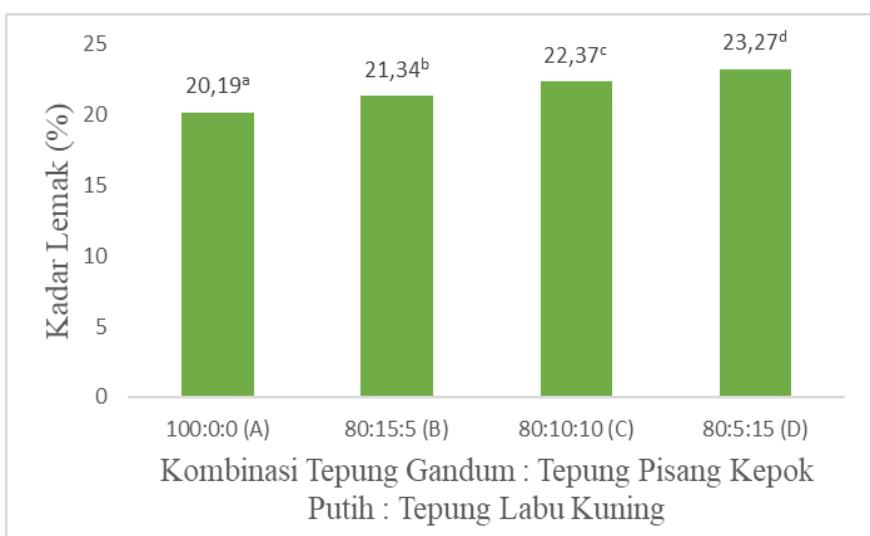

Gambar 3. Kadar Lemak Muffin dengan Kombinasi Tepung Pisang Kepok Putih dan Tepung Labu Kuning

Kenaikan kadar lemak pada muffin dengan kombinasi tepung pisang kapok putih dan tepung labu kuning disebabkan karena kandungan lemak pada tepung pisang kapok putih cenderung lebih rendah $(1,54 \%)$ dibandingkan dengan kadar lemak tepung labu kuning $(2,17 \%)$, sehingga semakin banyak penambahan tepung labu kuning, maka kadar lemak akan semakin meningkat. Reaksi hidrolisis lemak pada muffin dapat terjadi pada makanan yang memiliki kandungan air tinggi. Hidrolisis lemak menjadi asam lemak dan gliserol yang dipengaruhi oleh air. Apabila reaksi hidrolisis semakin banyak terjadi maka gliserol dan asam lemak mengalami peningkatan sehingga kadar lemak yang dihasilkan cenderung menurun (Kusnandar, 2010). 


\section{Kadar Protein}

Hasil analisis kadar protein muffin dengan kombinasi tepung pisang kapok putih dan tepung labu kuning berkisar antara 8,06-11,14 \%. Hasil analisis memiliki hasil yang berbeda nyata antara perlakuan kontrol dengan perlakuan kombinasi. Pada SNI roti manis (1995) tidak dicantumkan jumlah standar protein yang dapat digunakan sebagai pembanding hasil.

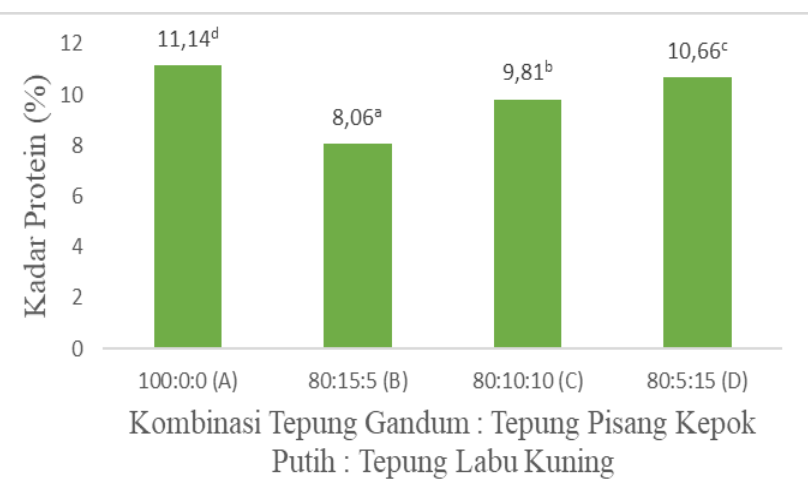

Gambar 4. Kadar Protein Muffin dengan Kombinasi Tepung Pisang Kepok Putih dan Tepung Labu Kuning

Kadar protein muffin dengan kombinasi tepung pisang kapok putih dan tepung labu kuning cenderung mengalami penurunan. Kandungan protein tepung pisang kapok putih sebesar $3,43 \%$, sedangkan pada tepung labu kuning sebesar $7,82 \%$, sehingga muffin dengan penambahan tepung labu kuning yang semakin meningkat maka kadar protein juga akan meningkat. Protein pada produk pangan dapat berguna sebagai pengikat yang dapat meningkatkan cekaman air di dalam produk karena terdapat molekul asam amino yang berperan dalam pembentukan ikatan peptida yaitu satu molekul air yang dibebaskan. Molekul protein tinggi pada produk pangan dapat mengikat uap air dengan baik yang disebabkan karena pengikatan air dari asam amino rantai samping yang disebut hidrokarbon. Suhu pemanggangan lebih dari suhu 55-75 ${ }^{\circ} \mathrm{C}$ mengakibatkan denaturasi protein sehingga ikatan peptida lebih mudah mengalami hidrolisis oleh proteolitik maka kelarutan protein menjadi tinggi (Kusnandar, 2010).

\section{Kadar Karbohidrat}

Hasil analisis karbohidrat pada muffin dengan kombinasi tepung pisang kapok putih dan tepung labu kuning berkisar antara 46,63-49,73\%. Hasil analisis karbohidrat memiliki beda nyata antar perlakuan kontrol dengan perlakuan kombinasi. Pada SNI roti manis (1995) tidak dicantumkan jumlah standar karbohidrat yang dapat digunakan sebagai pembanding hasil.

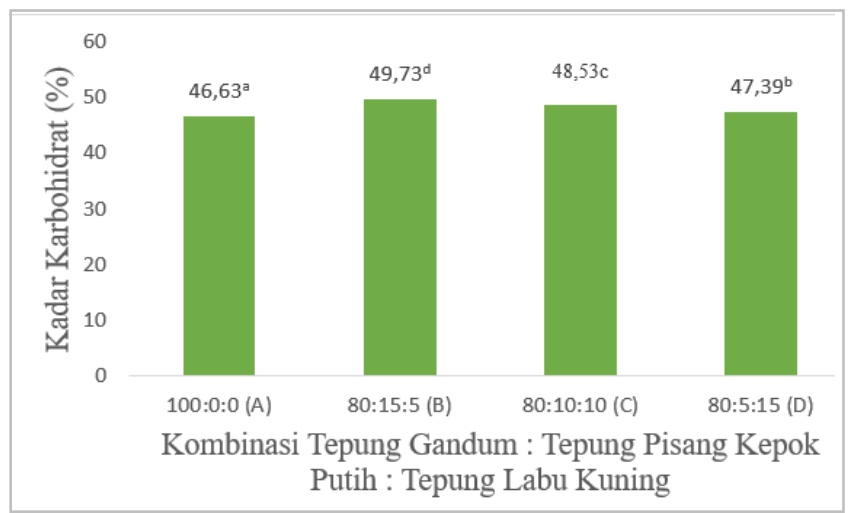

Gambar 5. Kadar Lemak Muffin dengan Kombinasi Tepung Pisang Kepok Putih dan Tepung Labu Kuning 
Produk muffin dengan konsentrasi tepung labu kuning yang tinggi (80:5:15) dapat diperoleh kadar karbohidrat lebih rendah dibandingkan dengan produk muffin dengan kandungan tepung pisang kepok putih dengan konsentrasi tinggi (80:15:5). Pisang kepok putih mengandung fruktooligosakarida (FOS) termasuk dalam golongan oligosakarida sekitar $0,3 \%$ sebagai sumber prebiotik dan tergolong dalam pati yang tidak dapat dicerna oleh enzim pencernaan di usus halus dan ketika mencapai usus besar dimanfaatkan oleh mikroflora kolon (Umam dkk., 2012).

\section{Kadar Serat Pangan}

Kadar serat pangan terdiri dari serat kasar (insoluble dietary fiber) dan serat larut (soluble dietary fiber). Hasil analisis serat pangan pada muffin memiliki beda nyata antar perlakuan kontrol dengan perlakuan kombinasi.

Pada SNI roti manis (1995) tidak dicantumkan jumlah standar serat pangan yang dapat digunakan sebagai pembanding hasil.

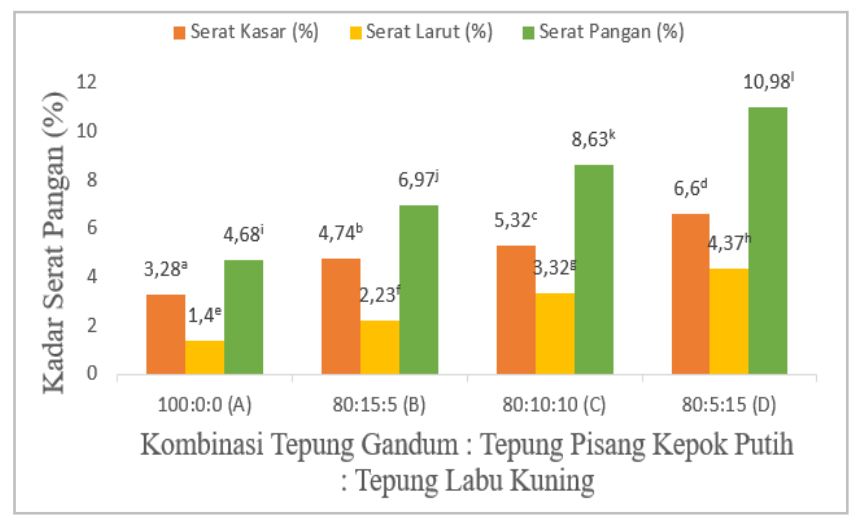

Gambar 6. Kadar Serat Pangan Muffin dengan Kombinasi Tepung Pisang Kepok Putih dan Tepung Labu Kuning

Kadar serat kasar, serat larut hingga serat pangan yang dihasilkan cenderung mengalami peningkatan dari muffin perlakuan kontrol hingga perlakuan muffin dengan konsentrasi tepung labu kuning yang lebih tinggi (80:5:15). Hasil proksimat kadar serat kasar dan serat larut yang dimiliki oleh tepung pisang kepok putih sebesar 4,09\% dan 3,68\% sedangkan tepung labu kuning memiliki kandungan serat kasar dan serat larut sebesar 6,55 \% dan 5,28 \% dapat memengaruhi kadar serat pangan yang terkandung pada produk muffin yang dihasilkan.

Penambahan serat pangan dapat meningkatkan kualitas dan stabilitas sehingga dapat memberikan nilai gizi bagi produk pangan yang dihasilkan namun serat larut memiliki sifat mudah tercampur dan mengikat kandungan air di dalam produk dibandingkan dengan serat tidak larut sehingga dapat memengaruhi tekstur bahkan kadar air pada produk pangan. Proses pemanasan dapat mengubah kandungan serat pangan dengan cara perubahan rasio serat larut menjadi serat kasar yang mengakibatkan kenaikan dari kadar serat tidak larut. Peningkatan kadar serat tidak larut dapat disebabkan karena proses pembentukan pati resisten terhadap proses pemanasan yang dapat terhitung sebagai serat tak larut. Perubahan tersebut terjadi karena kandungan serat tidak larut dan serat pangan meningkat seiring dengan penambahan tepung pisang kepok putih dan tepung labu kuning (Dhingra dkk., 2012).

\section{Kadar Betakaroten}

Betakaroten adalah salah satu dari senyawa karotenoid yang memiliki aktivitas pro-vitamin A yang dapat dikonversi didalam saluran pencernaan oleh sistem enzim menjadi retinol 
kemudian dapat berfungsi sebagai vitamin A. Hasil analisis betakaroten pada muffin memiliki beda nyata antar perlakuan kontrol dengan perlakuan kombinasi. Pada SNI roti manis (1995) tidak dicantumkan jumlah standar betakaroten yang dapat digunakan sebagai pembanding hasil.

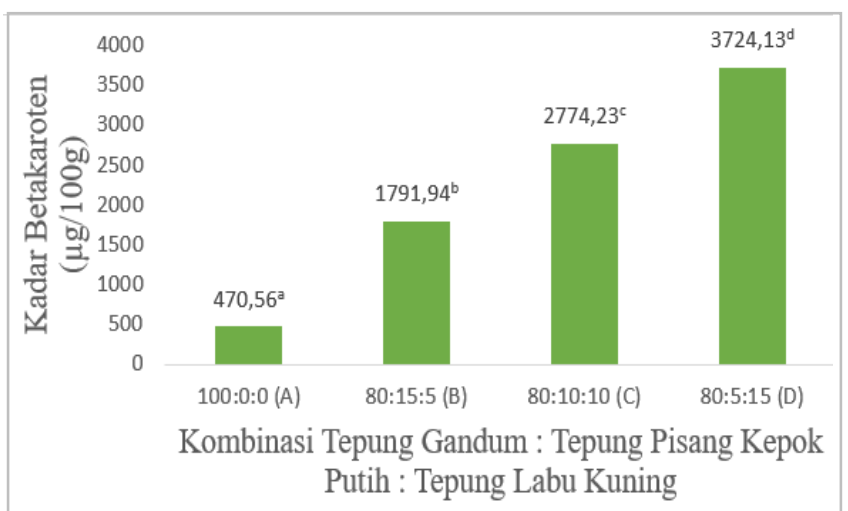

Gambar 7. Kadar Betakaroten Muffin dengan Kombinasi Tepung Pisang Kepok Putih dan Tepung Labu Kuning

Kadar betakaroten muffin dapat dilihat bahwa kadar betakaroten pada muffin mengalami peningkatan seiring dengan jumlah penambahan konsentrasi tepung labu kuning yang digunakan. Pada muffin dengan perlakuan kontrol (100:0:0) terdapat kandungan betakaroten dalam jumlah yang lebih sedikit dibandingkan dengan muffin dengan perlakuan kombinasi kedua tepung walaupun tidak terdapat penambahan tepung labu kuning karena pengaruh dari penggunaan butter dan susu untuk proses pembuatan muffin. Butter memiliki betakaroten dari lemak susu yang dipasteurisasi dan difermentasi agar memperoleh flavor khas butter. Kandungan betakaroten pada susu dapat diperoleh dari proses pengolahan untuk menghasilkan banyak karoten sehingga dapat mencegah fotooksidasi produk susu tersebut (Ollilainen dkk., 2015).

Durasi pemanasan dapat memengaruhi kandungan betakaroten. Suhu pemanasan minyak sawit merah sebesar $150{ }^{\circ} \mathrm{C}$ selama 2 jam mampu memiliki kadar betakaroten lebih tinggi dibandingkan dengan kandungan betakaroten dengan suhu $180{ }^{\circ} \mathrm{C}$ dengan durasi pemanasan yang sama. Kadar betakaroten pada suhu $150-180 \quad{ }^{\circ} \mathrm{C}$ dengan lama pemanasan kurang dari 30 menit masih mampu mempertahankan kandungan betakaroten di dalam minyak sawit merah. Proses pengolahan produk muffin dilakukan selama 20 menit pada rentang suhu $150-170{ }^{\circ} \mathrm{C}$ sehingga tidak terjadi penurunan kadar betakaroten di dalam produk dan mengalami peningkatan betakaroten seiring dengan peningkatan konsentrasi tepung labu kuning yang digunakan (Budiyanto dkk., 2010). Perlakuan pemanasan seperti perebusan dan dapat meningkatkan ketersediaan betakaroten pada labu kuning. Pemanasan mengakibatkan kerusakan struktur selulosa sel tanaman dan dengan demikian meningkatkan ketersediaan hayati karotenoid(Azizah dkk., 2009).

\section{Analisis Fisik Muffin}

\section{Analisis Tekstur}

Parameter utama yang digunakan dalam pengujian produk muffin adalah tingkat kekerasan. Penelitian ini dilakukan pengujian tekstur dengan alat Texture Analyzer dengan probe 41. Hasil analisis tekstur pada muffin memiliki beda nyata antar perlakuan kontrol dengan perlakuan kombinasi. 


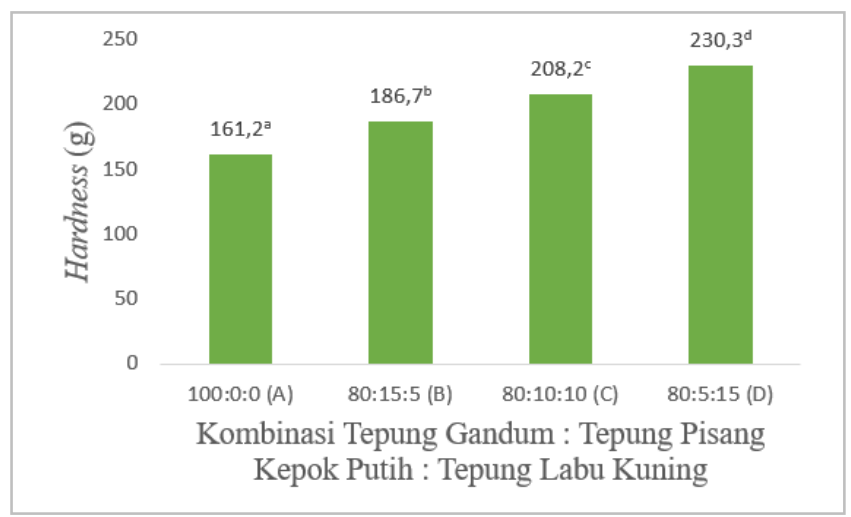

Gambar 8. Analisis Tekstur Muffin dengan Kombinasi Tepung Pisang Kepok Putih dan Tepung Labu Kuning

Tekstur muffin yang diperoleh cenderung meningkat seiring dengan penambahan tepung pisang kepok putih dan tepung labu kuning. Kandungan amilosa pada tepung labu kuning sebesar 20-25 \% dan amilopektin sebesar 75-80 \% (Adubofuor dkk., 2018). Kandungan amilosa pada tepung gandum sebesar 10,23 \% dan amilopektin sebesar 89,77 \% (Imanningsih, 2012). Kandungan amilosa pada tepung pisang kepok putih sebesar 19,2 \% dan kandungan amilopektin sebesar 80,8 \% (Wibowo dkk., 2008).

Kadar amilosa pada pati dari kedua tepung yang digunakan dapat menghasilkan tingkat kekerasanpada produk yang berbeda nyata. Semakin rendah kandungan amilosa di dalamnya maka dapat terjadi peningkatan kadar air. Amilosa memiliki ciri khas berupa struktur lurus dan memiliki gugus hidroksil maka air lebih mudah terikat dengan gugus hidroksil. Ikatan hidrogen antara amilosa dan air mudah lepas saat melalui proses pemanasan karena amilosa terletak bebas pada granula pati. Kandungan amilosa pada tepung labu kuning yang tinggi mengakibatkan produk muffin menjadi bertambah keras (Kusnandar, 2010).

\section{Analisis Warna}

Analisis warna pada produk dapat menggunakan alat color reader Konika Minolta seri CR-14. Hasil analisis warna dapat dilihat pada Tabel 3.

Tabel 3. Hasil Analisis Warna Muffin dengan Kombinasi Tepung Pisang Kepok Putih dan Tepung Labu Kuning

\begin{tabular}{cc}
\hline Sampel & Warna \\
\hline A & Putih kekuningan \\
B & Jingga kekuningan \\
C & Jingga kekuningan \\
D & Jingga kekuningan \\
\hline
\end{tabular}

Tepung pisang kepok putih memiliki warna putih kecokelatan yang diakibatkan dari reaksi pencokelatan yang terjadi secara non enzimatis antara gula pereduksi dan gugus amin pada asam amino/ protein akibat dari suhu tinggi sehingga terjadi pembentukan warna cokelat dan perubahan flavor (Morales dan Boekel, 1998). Penambahan tepung labu kuning dapat menghasilkan muffin semakin berwarna kekuningan. Warna kuning yang dihasilkan berasal dari pigmen yang terkandung dari senyawa karotenoid pada tepung labu kuning (Noviati dan Purwani, 2017). Warna muffin yang berubah menjadi berwarna kuning kecokelatan disebabkan oleh reaksi Maillard. Perubahan warna pada produk muffin dapat terjadi dari warna kuning lemah hingga cokelat gelap namun tergantung pada jalan reaksi serta jenis bahan yang digunakan (Morales dan Boekel, 1998). 
Analisis Mikrobiologi Muffin

\section{Angka Lempeng Total (ALT)}

Angka Lempeng Total adalah analisis mikrobiologi untuk menentukan tingkat higienis dan kualitas suatu produk (Fardiaz dan Margino, 1993). Pada SNI roti manis
(1995) jumlah standar angka lempeng total yang diperoleh maksimal $10^{6}$. Hasil dari perlakuan muffin kontrol (100:0:0) menyerupai perlakuan muffin dengan konsentrasi 80:10:10 dan 80:5:15 namun terdapat beda nyata dengan muffin dengan konsentrasi 80:15:5.

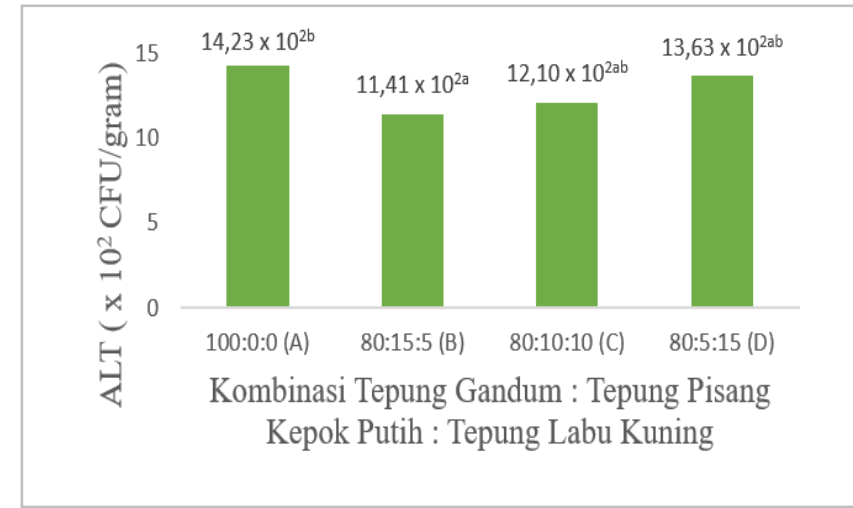

Gambar 9. Analisis Angka Lempeng Total Muffin dengan Kombinasi Tepung Pisang Kepok Putih dan Tepung Labu Kuning

Kandungan air dinyatakan dengan water activity $\left(\mathrm{a}_{\mathrm{w}}\right)$ berupa jumlah air bebas yang digunakan oleh mikroorganisme sebagai sumber pertumbuhannya. Jumlah mikrobia seperti bakteri, kapang dan khamir dapat berkaitan dengan $\mathrm{a}_{\mathrm{w}}$ berkisar 0,84-0,95 sehingga produk muffin sangat rentan terhadap ancaman dari segi mikrobiologis (Schmidt dan Fontana, 2007).

Tingginya angka lempeng total pada muffin kontrol (100:0:0) disebabkan karena semakin tinggi kandungan protein pada muffin maka jumlah bakteri akan semakin meningkat karena bakteri dapat tumbuh dan berkembang di produk pangan yang kaya akan nutrisi (Fardiaz, 1992). Muffin perlakuan B memiliki hasil ALT lebih rendah karena tepung pisang kepok putih memiliki kandungan pati yang memiliki kandungan prebiotik karena mengandung inulin dan FOS yang diberikan untuk nutrisi bakteri probiotik sehingga dapat meningkatkan aktivitas dari pertumbuhan Lactobacillus casei (Hardisari dan Amaliawati, 2016).

\section{Kapang Khamir (KK)}

Pengujian Angka Kapang Khamir (AKK) untuk menghitung jumlah kapang dan khamir. Pada SNI roti manis (1995) jumlah standar angka lempeng total yang diperoleh maksimal $10^{2}$.

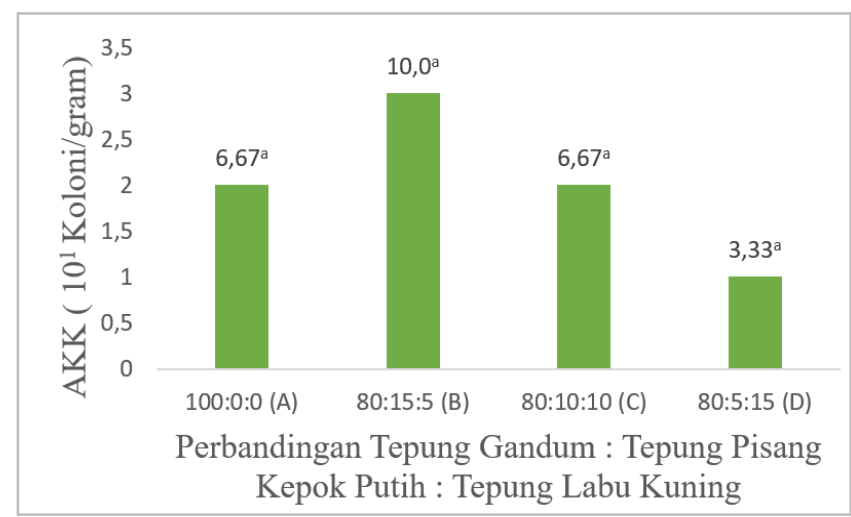

Gambar 10. Analisis Kapang Khamir Muffin dengan Kombinasi Tepung Pisang Kepok Putih dan Tepung Labu Kuning 
Roti manis dapat dikontaminasi oleh kapang dalam kondisi $\mathrm{a}_{\mathrm{w}}=0,65-1,00$ sedangkan khamir dapat mengkontaminasi roti manis dengan $a_{w}$ berkisar 0,84-0,95 (Schmidt dan Fontana, 2007). Jenis kapang yang dapat menyerang produk roti seperti Mucor sp., Cladosporium spp. dan Penicillium sp. sedangkan jenis khamir yang dapat mengkontaminasi jenis roti manis adalah Candida guililiermondii, Pichia burtonii dan Hansenula anomala (Sitanggang, 2017).

\section{Kesimpulan}

Produk muffin dengan kombinasi tepung pisang kapok putih dan tepung labu kuning dengan perbandingan kombinasi tepung gandum, tepung pisang kapok putih dan tepung labu kuning (80:15:5) dapat menghasilkan muffin dengan kualitas paling baik dilihat dari parameter fisik, kimia, organoleptik dan mikrobiologi.

\section{Daftar Pustaka}

Adubofuor, J., Anomah, J. W. \& Amoah, I. 2018. Antinutritional factors and mineral composition of pumpkin pulp and functional properties of pumpkin-wheat composite flour for bread preparation. Innovation Food Science Technology 1(1):1-9.

Aini, N. \& Rahayu, T. 2015. Media Alternatif untuk Pertumbuhan Jamur menggunakan Sumber Karbohidrat yang Berbeda. Prosiding Seminar Nasional XII Pendidikan Biologi FKIP. UNS, Surakarta.

Ambarita, M. D. Y., Bayu, E. S. \& Setiado, H. 2015. Identifikasi karakter morfologis pisang (Musa spp.) di Kabupaten Deli Serdang. Jurnal Agroekoteknologi 4(1):1911-1924.

Astawan, M. 1999. Membuat Mie dan Bihun. Penebar Swadaya, Jakarta.

Azizah, A. H., Wee, K. C., Azizah, O. \& Azizah, M. 2009. Effect of boiling and stir frying on total phenolics, carotenoids and radical scavenging activity of pumpkin. International Food Research Journal 16(1):45-51.

Badan Standarisasi Nasional. 1995. SNI 01-3840-1995 Tentang Roti Manis, Jakarta.

Budiyanto., Silsia, D., Efendi, Z. \& Janika, R. 2010. Perubahan kandungan $\beta$-karoten, asam lemak bebas dan bilangan peroksida minyak sawit merah selama pemanasan. Jurnal Agritech 30(2):75-79.
Cahyaningtyas, F. I., Basito. \& Anam, C. 2014. Kajian fisikokimia dan sensori tepung labu kuning Cucurbita moschata sebagai substitusi tepung terigu pada pembuatan egg roll. Jurnal Teknosains Pangan 3(2):13-19.

Damayanthi, E., Muchtadi, D., Syarief, H., Zakaria, F. R., Wijaya, C. H. \& Damardjati, D. S. 2003. Pengaruh derajat sosoh terhadap kandungan gizi serat pangan dan oryzanol bekatul padi (Oryza sativa) awet. Media Gizi dan Keluarga 27(1):104-114.

Dhingra, D., Michael, M., Raiput, H. \& Patil, R. T. 2012. Dietary fiber in foods. Journal Food Science Technology 49(3):255-266.

Fairudz, A. \& Nisa, K. 2015. Pengaruh serat pangan terhadap kadar kolestrol penderita overweight. Majority 4(8):121-126.

Fardiaz, S. \& Margino. 1993. Analisis Mikrobiologi Pangan. PAU Pangan dan Gizi Universitas Gadjah Mada, Yogyakarta.

Ferdiana, F. G., Pranata, S. \& Swasti, R. 2016. Kualitas biskuit dengan kombinasi tepung pisang kepok putih (Musa paradisiaca forma typica) dan tepung tempe. e-journal.uajy.ac.id. Universitas Atma Jaya Yogyakarta, Yogyakarta.

Hardiman, I. 2011. Cake Non Terigu untuk Jualan. Gramedia Pustaka Utama, Jakarta.

Hardisari, R. \& Amaliawati, N. 2016. Manfaat prebiotik tepung pisang kepok (Musa paradisiaca forma typica) terhadap pertumbuhan probiotik Lactobacillus casei secara in-vitro. Jurnal Teknologi Laboratorium 5(2):64-67.

Hutabarat, D. S. A. 2012. Hubungan penyusutan luas permukaan terhadap karakteristik pengeringan lapisan tipis singkong (Manihote sculenta Crantz). Naskah Skripsi S-1. FakultasTeknologiPertanianInstitutPertanian Bogor, Bogor.

Imanningsih, N. 2012. Profil gelatinisasi beberapa formulasi tepung-tepungan untuk pendugaan sifat pemasakan. Jurnal Penel Gizi Pangan 35(1):13-22.

Iqfar, A. 2012. Pengaruh dan penambahan tepung labu kuning dan tepung terigu terhadap pembuatan biskuit. Naskah Skripsi S-1. Fakultas Teknologi Pertanian UGM, Yogyakarta.

Kadir, S. 2005. Karakterisasi tepung empat varietas pisang di lembah Palu. Jurnal Agrisains 6(1):1-6

Kristianingsih, Z. 2010. Pengaruh substitusi labu kuning terhadap kualitas brownies kukus. Naskah Skripsi S-1. Fakultas Teknik Universitas Negeri Semarang, Semarang.

Kusnandar, F. 2010. Kimia Pangan : Komponen Makro. Dian Rakyat, Jakarta. 
Lestario, L. N., Susilowati, M. \& Martono, Y. 2012. Pemanfaatan Tepung Labu Kuning (Cucurbita moschata Durch) sebagai Bahan Fortifikasi Mie Basah. Prosiding Seminar Nasional Sains dan Pendidikan Sains VII. UKSW, Salatiga.

Lionora, G., Dewi, D. R. S. \& Rahaju, D. E. S. 2013. Analisis kelayakan bisnis kue muffin dari tepung uwi. Jurnal Widya Teknik 12(1):92102.

Marty, C. \& Berset, C. 1990. Factors affecting the thermal degradation of all trans beta-carotene. Journal Agriculture Food Chemistry 38(4):1063-1067.

Morales, F. J. \& Boekel, M. A. J. S. 1998. A study on advanced maillard reaction in heated casein/ sugar solutions: color formation. International Daily Journal 8(1):907-915.

Noviati, T. D. \& Purwani, E. 2017. Kadar Beta Karoten dan Daya Terima Cookies Garut dengan Substitusi Tepung Labu Kuning. Prosiding Seminar Nasional Gizi 2017 Program Studi Ilmu Gizi UMS, Surakarta.

Nugroho, A. H., Pranata, S. \& Purwijatiningsih, E. 2015. Kualitas sosis jamur tiram putih (Pleurotus ostreatus Jacq.) dan tepung labu kuning dengan kombinasi tepung tapioka dan karaginan (Euchema cottonii Doty.). $e$ journal.uajy.ac.id. Universitas Atma Jaya Yogyakarta, Yogyakarta.

Nurhayati., Jenie, B. S. L., Widowati, S. \& Kusumaningrum, H. D. 2014. Komposisi kimia dan kristalinitas tepung pisang termodifikasi secara fermentasi spontan dan siklus pemanasan bertekanan-pendinginan. Jurnal Agritech 34(2):146-150.

Ollilainen, V., Heinonen, M., Linkola, E., Varo, P. \& Koivistoinen, P. 2015. Carotenoids and retinoids in finnish foods: dairy foods and eggs. Journal of Dairy Science 72(1):22572265

Papunas, M. E., Djarkasi, G. S. S. dan Moningka, J. S. C. 2013. Karakteristik fisikokimia dan sensoris flakes berbahan baku tepung jagung (Zea mays L.), tepung pisang goroho (Musa acuminafe) dan tepung kacang hijau (Phaseolus radiates). Ejournal Unsrat 3(5): 1-10.

Pratama, R. I. 2011. Karakteristik fisikokimia dan sensoris snack bars tempe dengan penambahan salak pondoh kering. Naskah Skripsi S-1. Fakultas Perikanan dan Ilmu Kelautan, Institut Pertanian Bogor, Bogor.

Pratiwi, R. U. \& Rustanti, N. 2015. Kadar fenol total, aktivitas antioksidan dan tingkat kesukaan minuman fungsional jelly yoghurt srikaya dengan penambahan karagenan. Journal of Nutrition College 4(2):329-334.

Pujihastuti, I. 2010. Pengembangan proses inovatif kombinasi reaksi hidrolisis asam dan reaksi photokimia UV untuk produksi pati termodifikasi dari tapioka. Tesis $S-2$. Universitas Diponegoro, Semarang.

Purnomo, E. H., Sitanggang, A. B., Agustin, D. S., Hariyadi, P. \& Hartono, S. 2012. Formulation and process optimization of muffin produced from composite flour of corn, wheat and sweet potato. Jurnal Teknologi dan industri Pangan 23(2):165-172.

Ramachandran, P., Dhiman, A. K. \& Attri, S. 2017. Extraction of pectin from ripe pumpkin (Cucurbita moschata Duch ex. Poir) using eco-friendly technique. Journal of Ecology 44(6): 685-689.

Schmidt, S. J. \& Fontana, A. J. 2007. Water Activity Values of Select Food Ingredients and Products. Aplied Science Publiesher, London.

See, E. F. W., Nadiah. \& Noor, A. 2007. Physicochemical and organoleptic evaluations of wheat bread substitued with different percentage of pumpkin flour (Cucurbita moschata). ASEAN Food Journal 14(2): 123130.

Sitanggang, A. B. 2017. Faktor kerusakan produk bakery dan pengendaliannya. Food Review Indonesia 12(2):40-44.

Suladra, M. 2017. Optimasi fermentasi tepung singkong dan aplikasinya pada pembuatan makanan stik. Jurnal Agrotech 2(1):61-68.

Trisnawati, W., Suter, K., Suastika, K. \& Putra, N. K. 2014. Pengaruh metode pengeringan terhadap kandungan antioksidan, serat pangan dan komposisi gizi tepung labu kuning. Jurnal Aplikasi Teknologi Pangan 3(4):135-140.

Wibowo, P., Saputra, J. A., Ayucitra, A. \& Setiawan, L. E. 2008. Isolasi pati dari pisang kepok dengan menggunakan metode alkaline steeping. Jurnal Widya Teknik 7(2):113-123.

Winarno, F. G. 2004. Kimia Pangan. Gramedia Pustaka Utama, Jakarta. Halaman 54-79.

Yin, L. \& Wang, C. 2016. Morphological, thermal and physicochemical properties of starches from squash (Cucurbita maxima) and pumpkin (Cucurbita moschata). Journal of Horticulture 3(4):1-7.

Yuliana. \& Novitasari, R. 2014. Pengaruh subtitusi tepung gandum dengan tepung pisang kepok (Musa paradisiacal forma typica) terhadap karakteristik mie kering yang dihasilkan. Jurnal Teknologi Pertanian 3(1):1-14. 